\title{
CẮT THÙY PHỔI VÀ NẠO HẠCH QUA NỘI SOI LỒNG NGỰC TRONG ĐIỀU TR! UNG THƯ PHỔI KHÔNG TẾ BÀO NHỎ: AN TOÀN VÀ KHẢ THI?
}

\author{
Trần Minh Bảo Luân*, Nguyễn Hoài Nam*
}

\section{TÓM TẮT}

109 trường hợp ung thư phổi: tuổi trung bình $59,18 \pm 10,08(31-80)$, trong đó 59 nam $(54,1 \%), 50$ nữ $(45,9 \%)$. Kích thước u phổi: trung bình $3,23 \pm 0,91(1,2-5 \mathrm{~cm})$. Tổng cộng 419 vi trí hạch được phẫu thuật, 225 vị trí có hạch, phẫu thuật lấy hết 175 vị trí $(77,7 \%)$, không hết 30 vị trí (13,3\%). Thời gian phẫu thuật $128,8 \pm 31,3$ (70 - 220 phút), thời gian DLMP $3,1 \pm 1,8(2-$ 14 ngày), thời gian nằm viện $5,9 \pm 1,9(4-18$ ngày). Tai biến phẫu thuật: không tai biến 107 trường hợp $(98,2 \%), 1$ trường hợp rách tĩnh mạch đơn $(0,9 \%), 1$ trường hợp rách phế quản đối bên $(0,9 \%)$. Có 3 trường hợp Chuyển mổ nội soi hỗ trợ $(2,7 \%)$ do khó khăn khi nạo hạch và 1 trường hợp chuyển mở ngực $(0,9 \%)$ do rách mạch máu lớn. Biến chứng hậu phẫu: 2 trường hợp dò khí kéo dài $(1,8 \%), 1$ trường hợp viêm phổi $(0,9 \%), 1$ trường hợp suy hô hấp phải thở máy $(0,9 \%)$. Phẫu thuật nội soi lồng ngực cắt thùy phổi và nạo hạch cho thấy nhiều ưu điểm. Tính khả thi và an toàn về mặt kỹ thuật, hiệu quả trong điều trị ung thư cũng đã được nhiều tác giả chứng minh qua nhiều nghiên cứu. Nghiên cứu của chúng tôi cũng góp phần chứng minh những ưu điểm này.

Từ khóa: phẫu thuật nội soi lồng ngực, cắt thùy phổi và nạo hạch, ung thư phổi.

\section{SUMMARY}

LOBECTOMY AND LYMPHADENECTOMY VIA VIDEO-ASSITED THORACOSCOPIC SURGERY IN TREATMENT NON- SMALL CELL LUNG CANCER: IS SAFE AND FEASIBILITY?

109 cases of lung cancer: the mean age $59.18 \pm 10.08$ (31-80), of which 59 male (54.1\%),
50 female (45.9\%). The mean size of tumor: 3.23 $\pm 0.91(1.2-5 \mathrm{~cm})$. A total of 419 lymph node stations were explored, 225 lymph node stations were shown to be there, 175 lympho node stations completely removed (77.7\%), and 30 stations not completely removed (13.3\%). The mean operative time was $128.8 \pm 31.3(70-220$ $\mathrm{min})$, the mean duration of chest drainage was 3.1 \pm 1.8 ( 2 - 14 days) and of hospital stay was $5.9 \pm$ 1.9 (4 - 18 days). Intraoperative complications: 107 cases no complication (98.2\%), 1 case laceration of azygos vein $(0.9 \%), 1$ case laceration of ipsilateral main bronchus $(0.9 \%)$. There were 3 cases switched to a-VATS (2.7\%) due to difficulty in lympho nodal dissections and 1 case switched to thoracotomy $(0.9 \%)$ due to massive bleeding. Postoperative complications: 2 cases prolonged air leak (1.8\%), 1 case pneumonia $(0.9 \%), 1$ case respiratory failure requiring mechanical ventilation $(0.9 \%)$. VATS lobectomy and lymphadenectomy shows many advantages. Technological feasibility and safety, and effectiveness in cancer control have also been demonstrated by numerous studies. Our research also contributes to these advantages.

Keywords: Video-Assited Thoracoscopic Surgery (VATS), Lobectomy and Lymphadenectomy, Lung cancer.

\section{I. ĐẠTT VẤN ĐỀ}

Ung thư phổi là bệnh lý rất thường gặp trong dân số, chiếm tỷ lệ cao nhất trong các loại

\footnotetext{
* Bộ môn phẫu thuật Lồng Ngưc - Tim Mạch, Đại học Y Dược TPHCM Ngưòi chịu trách nhiệm khoa học: PGS.TS. Nguyễn Hoài Nam Ngày nhận bài: 01/05/2018 - Ngày Cho Phép Đăng: 20/05/2018

Phản Biện Khoa học: PGS.TS. Đặng Ngọc Hùng GS.TS. Lê Ngọc Thành
} 
ung thư tại Việt Nam. Trước đây, phẫu thuật điều trị ung thư phổi được thực hiện bằng phẫu thuật mở ngực kinh điển, với vết mổ dài hơn $15 \mathrm{~cm}$ và banh các xương sườn để vào lồng ngực và các thùy phổi bị ung thư. Với vết mổ dài và thao tác banh xương sườn nên bệnh nhân rất đau sau phẫu thuật, thậm chí nhiều trường hợp đau dai dẳng kéo dài dù đã được phẫu thuật trước đó nhiều tháng. Ngày nay, với sự tiến bộ của khoa học kỹ thuật, sự ra đời của hệ thống thấu kính, camera nội soi và các dụng cụ phẫu thuật, thiết bị cắt và khâu phổi tự động đã tạo ra kỹ nguyên mới trong phẫu thuật. Đến năm 1992, cắt thùy phổi bằng phẫu thuật nội soi lồng ngực lần đầu tiên được thực hiện thành công. Ngày nay, nhiều trung tâm trên thế giới đã áp dụng kỹ thuật này. Tuy nhiên, về mặt kỹ thuật thì cũng còn nhiều vấn đề: có nên nạo hạch triệt để hay chỉ lấy mẫu hạch, tính an toàn và khả thi của nạo hạch triệt để theo hệ thống,... được bàn cải nhiều trong phẫu thuật nội soi lồng ngực điều trị ung thư phổi. Trên cơ sở đó, chúng tôi thực hiện nghiên cứu nhằm đánh giá tính khà thi và an toàn của phẫu thuật nội soi lồng ngực cắt thùy phổi và nạo hạch trong điều trị ung thư phổi không tế bào nhỏ.

\section{Mục tiêu nghiên cứu:}

Đánh giá tính khả thi và an toàn của phẫu thuật nội soi lồng ngực cắt thùy phổi và nạo hạch trong điều trị ung thư phổi nguyên phát không tế bào nhỏ.

\section{II. ĐỐI TƯợNG VÀ PHƯƠNG PHÁP NGHIÊN CÚU}

Thiết kế nghiên cứu: tiền cứu mô tả dọc, không nhóm chứng.

Đối tượng nghiên cứu: tất cả bệnh nhân ung thư phổi nguyên phát không tế bào nhỏ được điều trị bằng phẫu thuật nội soi lồng ngực cắt thùy phổi kèm nạo hạch tại BV Đại học $\mathrm{Y}$ Dược TPHCM và $B V$ Phạm Ngọc Thạch từ 01/01/2012 đến $31 / 12 / 2016$.

Chỉ định áp dụng cắt thùy phổi và nạo hạch bằng PT NSLN: ung thư phổi giai đoạn I, IIA, IIIA (T2a,N2) (Định giai đoạn ung thư phổi: phân loại TMN $7^{\text {th }}$ Edition theo UICC hay AJCC 2009); kích thước $\mathrm{u}$ nhỏ hơn $5 \mathrm{~m}$ nằm ở ngoại biên, không xâm lấn mạch máu, thành ngực, rãnh liên thùy, cơ hoành và màng ngoài tim; bệnh nhân không xạ trị vùng ngực trước đó.

\section{KẾT QUẢ NGHIÊN CÚU}

Tuổi và giới: 109 trường hợp ung thư phổi: tuổi trung bình $59,18 \pm 10,08(31-80)$, trong đó 59 nam $(54,1 \%), 50$ nữ $(45,9 \%)$.

Đặc điểm của khối u phổi trên CT scan ngực có cản quang

Vị trí u phổi: Phổi $(\mathrm{P})$ : thùy trên 22 trường hợp $(20,2 \%)$, thùy giữa 14 trường hợp $(12,8 \%)$ và thùy dưới 30 trường hợp $(27,5 \%)$. Phổi $(\mathrm{T})$ : thùy trên 25 trường hợp $(22,9 \%)$ và thùy dưới 18 trường hợp $(16,5 \%)$.

Kích thước u phổi: trung bình 3,23 $\pm 0,91$ $(1,2-5 \mathrm{~cm}) .7$ trường hợp $\mathrm{u} \leq 2 \mathrm{~cm}(6,4 \%), 24$ trường hợp $\mathrm{u}>2-3 \mathrm{~cm}(22 \%), 78$ trường hợp $\mathrm{u}$ $>3-5 \mathrm{~cm}(71,6 \%)$

Tình trạng rãnh liên thùy: 39 trường hợp thấy được trên CT scan (64,2\%), 70 trường hợp không thấy được $(35,8 \%)$

Đặc điểm hạch rốn phổi và trung thất trên CT scan: trong 109 bệnh nhân, có 419 vị trí hạch được khảo sát CT scan cho thấy 225 $(53,7 \%)$ vị trí phát hiện có hạch và 194 vị trí không có hạch. 
Bảng 3.1: Vị trí và kích thước hạch trên CT scan

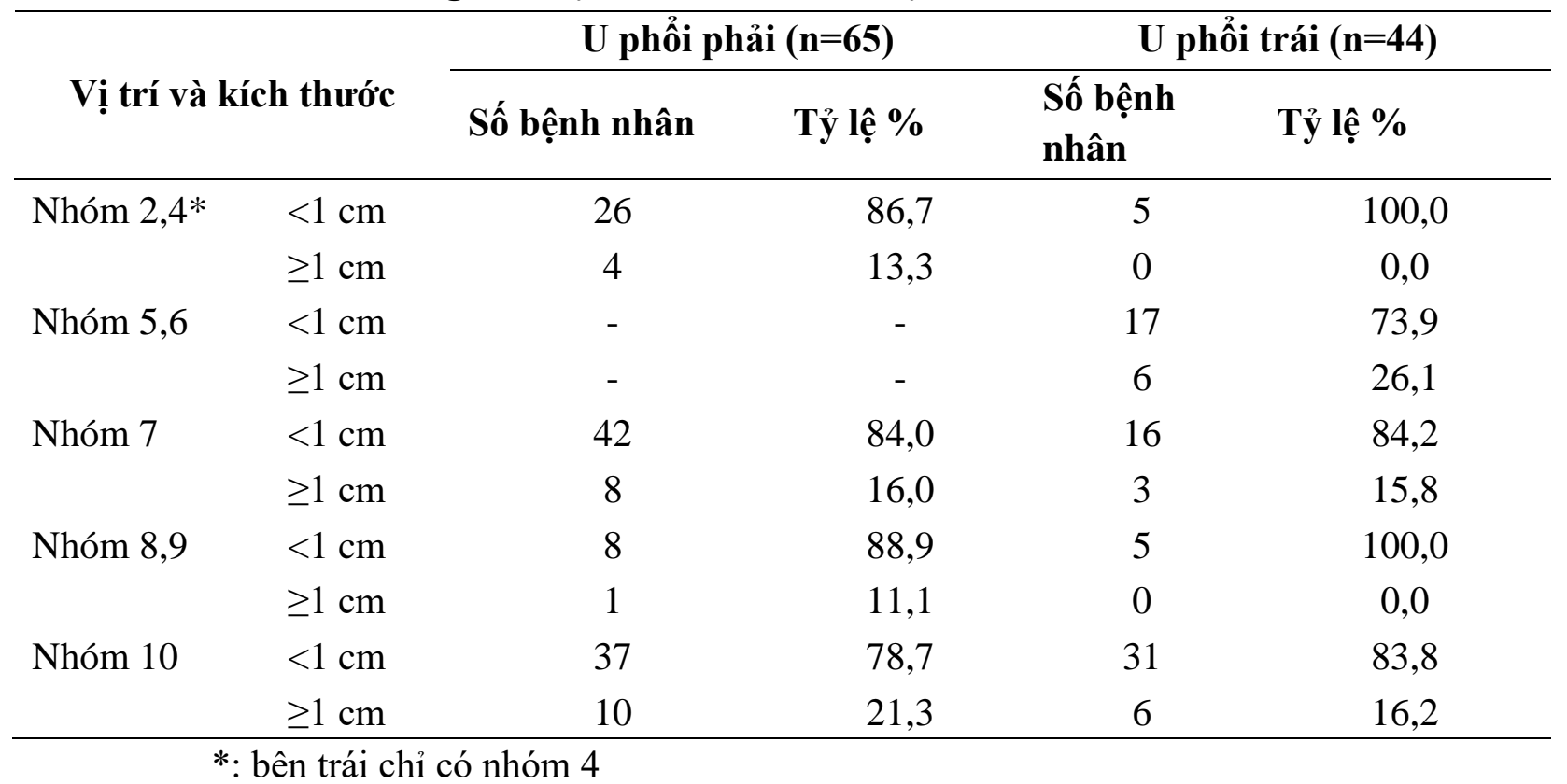

\section{Phẫu thuật}

Bảng 3.2: Các yếu tố liên quan trong phẫu thuật

\begin{tabular}{lcc}
\hline Đặc điểm & Số bệnh nhân & Tỷ lệ \% \\
\hline Dính phô̂i & 72 & 66,1 \\
Không & 28 & 25,7 \\
Dính ít & 9 & 8,3 \\
Dính nhiều & & \\
Rãnh liên thùy & 53 & 48,6 \\
Hoàn toàn & 42 & 38,5 \\
Không hoàn toàn & 14 & 12,8 \\
Dính rãnh liên thuỳ & & \\
Phương pháp phẫu thuật & 105 & 96,4 \\
Nội soi hoàn toàn & 3 & 2,7 \\
Chuyển NSLN hỗ trợ ${ }^{1}$ & 1 & 0,9 \\
Chuyển mố mở ${ }^{2}$ & & 14,3 \\
Chiều dài vết mổ & \\
<4 cm & 15 & 85,8 \\
4 - 6 cm & 90 & 98,2 \\
Tai biến phẫu thuật & & 0,9 \\
Không & 107 & 0,9 \\
Rách TM đơn & 1 & \\
Rách phế quản đối bên ${ }^{4}$ & 1 & \\
\hline
\end{tabular}

${ }^{1}: 1$ truờng hơp hạch 4L, 1 truòng hợp $7 R, 1$ truòng hơp $10 R$

${ }^{2}$ : chảy máu do rách tĩnh mạch đơn khi nạo hạch $2 R, 4 R$

${ }^{3}$ :Tính trên tổng 105 truờng hợp mổ nội soi hoàn toàn

${ }^{4}$ :xủ lý được qua nội soi lồng ngục 
Bảng 3.3: Thời gian phẫu thuật, lượng máu mất, thời gian DLMP và nằm viện

\begin{tabular}{lcccc}
\hline Đặc điểm & Trung bình & ĐLC & Nhỏ nhất & Lớn nhất \\
\hline Thời gian phẫu thuật (phút) & 128,8 & 31,3 & 70 & 220 \\
Máu mất (mL) & 165,1 & 95,6 & 50 & 600 \\
Thời gian DLMP (ngày) & 3,1 & 1,8 & 2 & 14 \\
Thời gian nằm viện (ngày) & 5,9 & 1,9 & 4 & 18 \\
\hline
\end{tabular}

Bảng 3.4: Biến chứng hậu phẫu

\begin{tabular}{lcc}
\hline Biến chứng hậu phẫu & Số bệnh nhân & Tỷ lệ \% \\
\hline Không & 105 & 96.3 \\
Dò khí kéo dài & 2 & 1.8 \\
Viêm phổi & 1 & 0.9 \\
Suy hô hấp, thở máy & 1 & 0.9 \\
\hline
\end{tabular}

Bảng 3.5: Giai đoạn ung thư phổi trước và sau phẫu thuật

\begin{tabular}{|c|c|c|c|c|c|}
\hline \multirow{2}{*}{ Giai đoạn trên CT scan } & \multicolumn{4}{|c|}{ Giai đoạn sau mổ } & \multirow{2}{*}{$\begin{array}{c}\text { Độ chính xác } \\
\text { của CT scan (\%) }\end{array}$} \\
\hline & IA & IB & IIA & IIIA & \\
\hline IA & 19 & 5 & 0 & 0 & \multirow{5}{*}{$71,6 \%$} \\
\hline $\mathrm{IB}$ & 6 & 28 & 4 & 4 & \\
\hline IIA & 0 & 1 & 13 & 10 & \\
\hline IIIA & 0 & 0 & 1 & 18 & \\
\hline Tổng số (109) & 25 & 34 & 18 & 32 & \\
\hline
\end{tabular}

Khả năng phẫu thuật lấy hết hạch: trong 109 trường hợp được phẫu thuật, có tổng cộng 419 nhóm hạch về phương diện phẫu thuật được khảo sát: 110 vị trí không có hạch trong mổ, 279/309 vị trí lấy được hết hạch (90,3\%), 30/309 không lấy được hết hạch $(9,7 \%)$.

Bảng 3.6: Khả năng phẫu thuật lấy hết các nhóm hạch trong mổ và trên CT scan Hạch thấy trên CT scan Hạch thấy trong mổ $(\mathrm{N}=309)$

Vị trí hạch $(\mathrm{N}=225)$

\begin{tabular}{|c|c|c|c|c|}
\hline \multirow{3}{*}{ Vị trí hạch } & \multirow{2}{*}{\multicolumn{2}{|c|}{ Phẫu thuật lấy hết }} & \multirow{2}{*}{\multicolumn{2}{|c|}{ Phẫu thuật lấy hết }} \\
\hline & & & & \\
\hline & Không & Có & Không & Có \\
\hline \multicolumn{5}{|l|}{ Bên phải } \\
\hline Nhóm 2,4 & $2(6,7)$ & $28(93,3)$ & $2(5,1)$ & $37(94,9)$ \\
\hline Nhóm 7 & $5(10,0)$ & $45(90,0)$ & $5(8,8)$ & $52(91,2)$ \\
\hline Nhóm 8,9 & $0(0,0)$ & $9(100,0)$ & $0(0,0)$ & $23(100,0)$ \\
\hline Nhóm 10 & $10(21,3)$ & $37(78,7)$ & $10(15,6)$ & $54(84,4)$ \\
\hline
\end{tabular}




\section{Bên trái}

\begin{tabular}{lrrrr} 
Nhóm 4 & $4(80,0)$ & $1(20,0)$ & $4(40,0)$ & $6(60,0)$ \\
Nhóm 5,6 & $2(8,7)$ & $21(91,3)$ & $2(6,5)$ & $29(93,5)$ \\
Nhóm 7 & $2(10,5)$ & $17(89,5)$ & $2(7,1)$ & $26(92,9)$ \\
Nhóm 8,9 & $0(0,0)$ & $5(100,0)$ & $0(0,0)$ & $13(100,0)$ \\
Nhóm 10 & $5(13,5)$ & $32(86,5)$ & $5(11,4)$ & $39(88,6)$ \\
Tổng số & $\mathbf{3 0 ( 1 3 , 3 )}$ & $\mathbf{1 7 5}(\mathbf{7 7 , 7})$ & $\mathbf{3 0}(\mathbf{9 , 7})$ & $\mathbf{2 7 9}(\mathbf{9 0 , 3})$ \\
\cline { 2 - 5 } *Phép kiểm chính xác Fisher & $\mathbf{P = \mathbf { 0 , 0 1 7 }}$ & $\mathbf{P}=\mathbf{0 , 0 4 9} *$
\end{tabular}

Nhận xét: trong 109 trường hợp, có 419 nhóm hạch được phẫu thuật nạo vét, khả năng phẫu thuật lấy hết hạch cao nhất tại hạch nhóm 8,9 cho cả hai bên $(100 \%)$, kế đến là hạch nhóm 2,4 bên phải $(94,9 \%)$ và hạch nhóm 7 hai bên $(91,2 \%$ và $92,9 \%)$; khả năng phẫu thuật lấy hết hạch thấp nhất tại vị trí 4 bên trái $(60 \%)$ và hạch nhóm 10 cả hai bên $(84,4 \%$ và $88,6 \%)$. $(\mathrm{P}=0,049)$.

Bảng 3.7: Khả năng phẫu thuật lấy hết hạch và kích thước hạch trong mổ, trên CT scan

\begin{tabular}{lccc}
\hline \multirow{2}{*}{ Kích thước hạch } & \multicolumn{2}{c}{ Phẫu thuật lấy hết } & Giá trị p \\
\cline { 2 - 3 } & Không & Có & \\
\hline Phẫu thuật & $8(3,3)$ & $236(96,7)$ & $<\mathbf{0 , 0 0 1 *}$ \\
$<1 \mathrm{~cm}$ & $22(33,9)$ & $43(66,2)$ & \\
$\geq 1 \mathrm{~cm}$ & & & \\
CT scan ngực & $15(8,0)$ & $172(92,0)$ & $<\mathbf{0 , 0 0 1 *}$ \\
$<1 \mathrm{~cm}$ & $15(39,5)$ & $23(60,5)$ & \\
$\geq 1 \mathrm{~cm}$ & &
\end{tabular}

*Phép kiểm Chi bình phương

Nhận xét: kích thước hạch đo được trên CT scan ngực hay trong mổ càng lớn thì khả phẫu thuật lấy được hết hạch càng thấp $(\mathrm{P}=0,001)$.

Bảng 3.8: Các yếu tố liên quan biến chứng sau mổ

\begin{tabular}{lccc}
\hline \multicolumn{1}{c}{ Yếu tố } & $\begin{array}{c}\text { Số biến chứng } \\
\text { (tỷ lệ \%) }\end{array}$ & OR $(\mathbf{K T C}$ 95\%) & Giá trị p \\
\hline $\begin{array}{l}\text { Tuổi } \\
\leq 60\end{array}$ & $1(1,8)$ & 1 & \\
$>60$ & $3(5,8)$ & $3,429(0,345-34,041)$ & 0,293 \\
Thời gian phẫu thuật (phút) & & $1,017(0,988-1,047)$ & 0,259 \\
Tình trạng phổi dính & & & \\
Không & $2(2,8)$ & 1 & 0,835 \\
Dính ít & $1(3,6)$ & $1,296(0,113-14,89)$ & 0,249 \\
Dính nhiều & $1(11,1)$ & $4,375(0,336-53,8)$ &
\end{tabular}


Tình trạng rãnh liên thuỳ

Không hoàn toàn

Hoàn toàn

Dính rãnh liên thuỳ

Lượng máu mất (mL)

Tai biến trong mổ

Không

Có

Chuyển NS hỗ trợ, mổ mở
Không
$4(3,8)$
Có
$0(0,0)$

Bệnh kèm theo

Không

Có

$2(5,7)$

Hút thuốc lá

Không

Có

$1(2,2)$

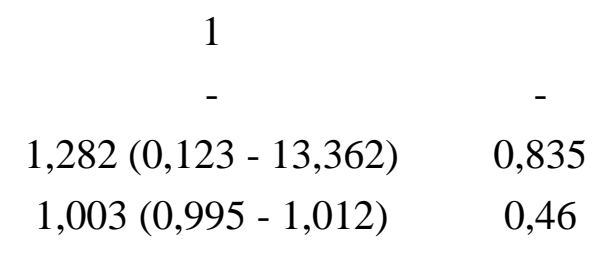

1

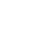

1

$-$

Nhận xét: tuổi cao, phổi dính nhiều, rãnh liên thùy không hoàn toàn, thời gian phẫu thuật kéo dài, lượng máu mất hay chuyển mổ mở và có bệnh kèm theo không liên quan đến biến chứng hậu phẫu.

\section{BÀN LUẬN}

\subsection{Khả năng phẫu thuật lấy hết các nhóm hạch theo vi trí hạch}

Trong 109 trường hợp, có 419 nhóm hạch được phẫu thuật nạo vét, chúng tôi nhận thấy: khả năng phẫu thuật lấy hết hạch (thấy được trên CT scan ngực và trong mổ) cao nhất tại hạch nhóm 8,9 cho cả hai bên $(100 \%)$, kế đến là hạch nhóm 2,4 bên phải $(94,9 \%)$ và hạch nhóm 7 hai bên (91,2\% và $92,9 \%)$; khả năng phẫu thuật lấy hết hạch thấp nhất tại vị trí 4 bên trái $(60 \%)$ và hạch nhóm 10 cả hai bên $(84,4 \%$ và $88,6 \%)$. ( $\mathrm{P}=$ $0,049)$. Các vị trí $2 \mathrm{R}, 4 \mathrm{R}, 8$ và 9 là các vị trí dễ tiếp cận và xung quanh là khí quản, thực quản có thành dày, cứng chắc hơn so với các vị trí hạch nằm cạnh mạch máu nên khả năng lấy hết được hạch cao hơn so với các vị trí khác nằm sâu hơn như hạch nhóm 7; hay dễ tổn thương mạch máu lớn khi bóc tách như hạch nhóm 10; Khó khăn nhất là hạch nhóm 4 bên trái, để tiếp cận được nhóm hạch này cần phải cắt dây chằng động mạch ngay cửa sổ phế - chủ, nên khả năng phẫu thuật hạn chế nhất. Tuy nhiên, theo một số tác giả thì không nhất thiết phải tiếp cận và nạo triệt căn hạch nhóm này vì chỉ có $2-4 \%$ tìm thấy hạch di căn tại vị trí này khi khối u nằm thùy trên phổi trái, tỷ lệ này còn ít hơn nữa khi khối u nằm ở thùy dưới. Nghiên cứu của Manser $R$ và $C S$ (2005) với 1910 BN UTP, cho thấy khả năng nạo hạch triệt để là $97 \%$ của phổi phải và $95 \%$ của phổi trái. Theo Miller Y.E (2006) các khối u phổi phải tỷ lệ nạo hạch triệt để ở chặng hạch N2 là $96 \%$, nhưng khối u phổi trái tỷ lệ này giảm còn $88 \%$. Nghiên cứu của Turna A. và cs (2007) cho biết: phổi phải, khi có u thùy trên, tỷ lệ lấy được hạch vị trí số 2 và 4 lên tới $96,5 \%$; khi u ở thùy dưới, tỷ lệ lấy được hạch số 7 là $88,1 \%$. Bên phổi 
trái, khi khối u ở thùy trên, tỷ lệ lấy được hạch số 5 và 6 là 92,5\%; khi u thùy dưới, tỷ lệ lấy được hạch là $96,0 \%$.

Ngoài tỷ lệ phẫu thuật nạo vét triệt để thành công cho từng vị trí hạch, một số tác giả còn báo cáo về số vị trí nhóm hạch nạo vét triệt để được trong mổ. Theo Scott W. J. và cs (2010), tổng số vị trí hạch vét được trong mổ là 4,3. Tác giả Marty Ane Ch. H. và cs (2013) cho biết số lượng hạch N2 vét được là 14,6 (từ 5 đến 44 hạch). Tác giả Lee $\mathrm{P}$. C. và cs (2013) báo cáo kết quả phẫu thuật nạo triệt căn các nhóm hạch cho bệnh nhân ung thư phổi không tế bào nhỏ, với giai đoạn trước mổ từ I đến III, cho thấy, số vị trí vét được hạch N1 là $1,4 \pm 0,5$, hạch N2 là $1,9 \pm 0,7$.

\subsection{Khả năng phẫu thuật lấy hết hạch theo kích thước hạch trong mổ}

Kết quả của chúng tôi cho thấy, trong 109 bệnh nhân, có 225 vị trí hạch thấy được trên $\mathrm{CT}$ scan, 187 vị trí có hạch $\leq 1 \mathrm{~cm}$, phẫu thuật lấy hết đạt $92 \%$, và 38 vị trí có hạch $\geq 1 \mathrm{~cm}$, khả năng phẫu thuật lấy hết chỉ $60,5 \%$. So với hạch được tìm thấy trong mổ, có 309 vị trí có hạch được phẫu thuật nạo vét, 244 vị trí có hạch $\leq 1 \mathrm{~cm}$, tỷ lệ phẫu thuật lấy hết $96,7 \%$, và 65 vị trí có hạch $\geq$ $1 \mathrm{~cm}$, tỷ lệ lấy hết chỉ $66,2 \%$. Qua đó, chúng tôi nhận thấy kích thước hạch trên CT scan hay trong mổ càng lớn thì khả phẫu thuật lấy được hết hạch càng thấp. $(\mathrm{P}=0,001)$. Tác giả Nguyễn Khắc Kiểm (2016) với $282 \mathrm{BN}$, khả năng nạo hạch triệt để giảm dần theo kích thước, kích thước hạch càng lớn khả năng xâm lấn nhiều nên nạo triệt để càng khó, đặc biệt những hạch xâm lấn mạch máu. Khả năng nạo triệt để cao đạt $97,9 \%$ ở nhóm hạch có kích thước $\leq$ $10 \mathrm{~mm}$; hạch $>10-20 \mathrm{~mm}$ tỷ lệ này giảm còn $91,4 \%$ và khi hạch lớn $>20 \mathrm{~mm}$ thì chỉ còn $80,0 \%$ được nạo vét triệt để $(\mathrm{P}=0,000)$.

Hiện tại, chúng tôi không tìm thấy nhiều thông tin của các tác giả nước ngoài báo cáo về vấn đề này, đa số các tác giả xoay quanh vấn đề có nên phẫu thuật nạo hạch triệt để theo bản đồ hạch hay chỉ cần lấy bỏ từng hạch; và dựa vào tỷ lệ sống còn làm thước đo cho hiệu quả của hai phương án trên, mà không thấy đề cập đến khả năng phẫu thuật lấy được hết và không hết hạch có liên quan đến các tính chất của hạch hay không. Theo tác giả Zongren G (2009), với 403 trường hợp, ghi nhận phẫu thuật nạo hạch đạt triệt để 93,1\%; không triệt để là 6,9\%; tỷ lệ tai biến ở mức chấp nhận được $5 \%$ và khả năng nạo hạch triệt để phụ thuộc vào vị trí của từng nhóm hạch. Tác giả Zhi X.Y (2010) trong một báo cáo phẫu thuật cắt thùy phổi kèm nạo hạch một cách hệ thống tại các vị trị hạch cho thấy tỷ lệ triệt để cao 95,7\%; không triệt để 4,3\%.

Ngoài $\mathrm{ra}$, có tác giả còn cho rằng chỉ cần lấy bỏ những hạch $(+)$, còn những hạch nhỏ được coi là $(-)$ thì không cần phải nạo vét để tránh nguy cơ tai biến. Tuy nhiên, các tác giả Nhật Bản với quan điểm tích cực, chủ động nạo hạch dự phòng một cách hệ thống tại tất cả các vị trí hạch theo bản đồ, đã chứng minh trên thực tế những hạch có kích thước $5-10 \mathrm{~mm}$ được cho là $(-)$ sau khi được phẫu thuật vẫn thấy 12 - 20\% là những hạch $(+)$.

\subsection{Tai biến trong mổ, chuyển PTNS hỗ trọ hay mổ mở}

Tai biến nguy hiểm nhất trong mổ thường là chảy máu lượng lớn do tổn thương mạch máu phổi. Trong PTNS, đường mổ nhỏ nên sẽ gây khó khăn cho phẫu thuật viên kiểm soát chảy máu. Tuy nhiên, nếu phẫu thuật được tiến hành bởi phẫu thuật viên nhiều kinh nghiệm, nguy cơ chảy máu lượng lớn ít xảy ra hơn, nhờ khả năng xử lý chảy máu của họ trong lúc phẫu thuật. Khi bóc tách mạch máu hay nạo các nhóm hạch gần mạch máu lớn, nếu có biến chứng chảy máu do tổn thương các nhánh mạch máu phổi, có thể kiểm soát bằng cách dùng kẹp gạc đè ép nơi chảy máu tạm thời và sau đó cố gắng cầm máu qua PTNS. Tuy nhiên, nếu chảy máu nhiều và lượng lớn, theo tác giả Todd Demmy, không nên do dự mà phải chuyển mổ mở ngay. 
Bảng 4.1: Tỷ lệ chuyển mổ mở của một số tác giả

\begin{tabular}{lccc}
\hline \multirow{2}{*}{ Tác giả } & \multirow{2}{*}{ Số bệnh nhân } & \multicolumn{2}{c}{ Chuyển mổ mở } \\
\cline { 3 - 4 } Kim R. H. và cs (2010) & 595 & Chảy máu nặng (\%) & Nguyên nhân khác (\%) \\
Kwhanmien Kim (2010) & 740 & 1,4 & 0 \\
Liang C. và cs (2013) & 382 & 1,6 & 3,5 \\
Walker W. S. và cs (2003) & 179 & 3,3 & 4,9 \\
Gonzalez (2011) & 200 & 5 & 7,9 \\
Amer K. và cs (2011) & 156 & 8,3 & 9,5 \\
Chúng tôi & $\mathbf{1 0 9}$ & $\mathbf{0 , 9}$ & 6,4 \\
& & & $\mathbf{2 , 7}$ \\
\hline
\end{tabular}

Theo Shigeki Sawada, nguyên nhân của chuyển mổ mở được chia làm hai nhóm:

- Nhóm 1: các nguyên nhân liên quan khó khăn kỹ thuật như: chảy máu khi bóc tách, chảy máu do staplers bị lỗi khi cắt mạch máu

- Nhóm 2: các nguyên nhân khác không liên quan đến kỹ thuật: hạch dính, rãnh liên thùy không hoàn toàn, phổi dính.

Trong 109 trường hợp của chúng tôi:

1. Chỉ 1 trường hợp chảy máu lượng lớn do rách TM đơn khi phẫu tích nạo hạch nhóm $2 \mathrm{R}$, $4 \mathrm{R}$ đòi hỏi phải mở ngực và 1 trường hợp rách phế quản gốc đối bên xữ lý được qua nội soi.

2. Có 3 trường chuyển nội soi hổ trợ trong đó:

1 trường hợp xảy ra khi nạo hạch nhóm 4L do vị trí giải phẫu nằm sâu, cần nhiều dụng cụ banh vén và nhìn trực tiếp để thao tác; khi phẫu thuật trường hợp này chúng tôi nhận thấy, dùng nhiều dụng cụ nội soi cùng lúc gây khó khăn cho góc quan sát của camera vì bị che khuất bởi các dụng cụ dùng để banh vén cùng lúc.

1 trường hợp nạo hạch nhóm 7R do hạch dính sát phần màng của phế quản và trường hợp này được phẫu thuật chỉ vài ngày sau trường hợp rách phế quản đối bên trước đó, được chúng tôi xử lý tốt qua nội soi, tâm lý lo ngại vẫn còn nên phẫu thuật viên chuyển nội soi hỗ trợ cho an toàn

1 trường hợp 10R do hạch dính chặt mạch máu lớn rốn phổi. Theo chúng tôi, khái niệm nội soi hỗ trợ hay chuyển mổ mở chỉ mang tính chất tương đối, vì nếu vẫn không thể thực hiện được qua nội soi hỗ trợ, sẽ tiếp tục mở rộng thêm vết mổ nhỏ cho đến khi thực hiện được. Lúc đó độ dài của vết mổ gần như được gọi là mở ngực kinh điển nhằm đảm bảo hiệu quả điều trị tối đa cho bệnh nhân.

\subsection{Các yếu tố liên quan biến chứng sau mổ:}

Biến chứng sau mổ của phẫu thuật nội soi cắt thùy phổi và nạo hạch là một vấn đề được nhiều tác giả quan tâm, được xem thước đo để đánh giá tính an toàn của phẫu thuật nội soi trong điều trị ung thư phổi. Dù có nhiều bước tiến về phương tiện và kỹ thuật trong gây mê, phẫu thuật và hồi sức, chăm sóc người bệnh nhưng tỷ lệ biến chứng sau mổ vẫn chưa khả quan. Theo Hiệp hội phẫu thuật lồng ngực Hoa Kỳ, từ 1999 đến 2006, với 49.029 bệnh nhân được phẫu thuật lồng ngực, trong đó $67,0 \%$ cắt thùy phổi và nạo hạch, tỷ lệ biến chứng sau mổ $32 \%$, trong đó xì khí kéo dài trên 5 ngày $8,0 \%$, viêm phổi $3,8 \%$, xẹp phổi $3,6 \%$. Kết quả của chúng tôi, có 4 trường hợp $(3,6 \%)$, trong đó 2 trường hợp xì khí kéo dài chỉ cần điều trị nội khoa, 1 trường hợp viêm phổi đáp ứng với điều trị kháng sinh, 1 trường hợp suy hô hấp phải thở máy kéo dài sau mổ, không có trường hợp nào tử vong trong hay sau mổ. Khi phân tích biến chứng, chúng tôi nhận thấy không có mối liên quan có ý nghĩa thống kê với các yếu tố như: tuổi cao, tình trạng dính phổi nhiều, rãnh liên thùy không hoàn toàn, thời gian phẫu thuật kéo dài, lượng máu mất hay chuyển mổ mở và có bệnh kèm theo. 
Trong nghiên cứu của Cù Xuân Thanh (2002) $\mathrm{n}=246 \mathrm{BN}$ chia ra 2 nhóm $\mathrm{BN}>60 \mathrm{~T}$ và nhóm $\leq 60 \mathrm{~T}$ cho thấy tỷ lệ tai biến và tử vong của hai nhóm không khác biệt nhiều. Nghiên cứu của Nguyễn Hoàng Bình, bệnh nhân có rãnh liên thùy không hoàn toàn có tỷ lệ biến chứng cao hơn so nhóm bệnh nhân có rãnh liên thùy hoàn toàn (11.9\% so với $6.1 \%$; và tỷ lệ biến chứng ở bệnh nhân phổi không dính thấp hơn so với nhóm bệnh nhân có phổi dính (10.7\% so với $8.3 \%)$. Tuy nhiên, cả hai đều khác biệt không có ý nghĩa thống kê. Hiroaki Nomori và cs nghiên cứu kết quả PTNS cắt thùy phổi và nạo hạch ở hai nhóm bệnh nhân có rãnh liên thùy hoàn toàn và không hoàn toàn. Ông nhận thấy không có sự khác biệt về thời gian phẫu thuật, lượng máu mất trong phẫu thuật, tỷ lệ biến chứng và tử vong giữa hai nhóm, đặc biệt là biến chứng dò khí. Báo cáo của Yamatoma $\mathrm{K}$. và cs (2010), phẫu thuật cắt phổi và nạo hạch cho 502 bệnh nhân, ghi nhận biến chứng sau mổ như sau: biến chứng chung $28 \%$, trong đó biến chứng hô hấp chiếm tỷ lệ $22,9 \%$, nhiều nhất là xì khí kéo dài trên 7 ngày $16,9 \%$, viêm phổi $1,8 \%$, suy hô hấp $0,3 \%$.

Qua kết quả của các tác giả trên, biến chứng thường gặp và nhiều nhất là xì khí kéo dài, điều này cũng phù hợp với kết quả của chúng tôi. Theo tác giả Elseyed $H$. và cs (2012) cho rằng: biến chứng xì khí kéo dài là nguyên nhân kéo dài thời gian nằm viện sau mổ (13 ngày so với 7 ngày, $\mathrm{p}<0,0001$ ), có bệnh phổi tắc nghẽn mạn tính kèm theo và phổi dính là yếu tố làm tăng tỷ lệ biến chứng này.

\section{KẾT LUẬN}

Phẫu thuật nội soi lồng ngực cắt thùy phổi và nạo hạch cho thấy nhiều ưu điểm: vết mổ nhỏ, thẫm mỹ cao, không banh kéo xương sườn nên ít đau sau mổ, thời gian phục hồi và nằm viện ngắn... Hiện nay, kỹ thuật này đang được áp dụng rộng rãi và tính khả thi và an toàn về mặt kỹ thuật, hiệu quả trong điều trị ung thư cũng đã được nhiều tác giả chứng minh qua nhiều nghiên cứu. Nghiên cứu của chúng tôi cũng góp phần chứng minh những ưu điểm này.

\section{TÀI LIỆU THAM KHẢO}

1. Alper $\mathrm{T}$ (2016). Lymph Node Dissection in Surgery for Lung Cancer: Comparison of Open vs. Video-Assisted vs. Robotic-Assisted Approaches. Ann Thorac Cardiovasc Surg; 22: 284-290.

2. Amer K, Khan A Z, Vohra H A (2011), Video - assisted thoracic surgery of major pulmonary resections for lung cancer: the Southampton experience, European Journal of Cardio-thoracic Surgery, 39, p. 173 - 179.

3. Boffa D J, Allen M S, Grab J D, et al. (2008). Data from The Society of Thoracic Surgeons General Thoracic Surgery database: The surgical management of primary lung tumors, The Journal of Thoracic and Cardiovascular Surgery, 135(2), p. 247 - 254.

4. Cù Xuân Thanh (2002). Nghiên cứu đặc điểm lâm sàng, $\mathrm{X}$-quang phổi qui ước, các type mô bệnh học và điều trị phẫu thuật ung thư phổi ở người trên 60 tuổi, Luận án tiến sĩ y học, Học viện Quân y.

5. Davis C J and Filipi C J (1997). A history of Endoscopy Surgery. Princles of Laparoscopic Surgery. Springer - Verlag. 1997: 3-20.

6. Demmy T L \& Jackie J C (1999). Minimally Invasive Lobectomy Directed Toward Frail and High-Risk Patients: A Case-Control Study, Ann Thorac Surg, 68, pp 194 -200.

7. Gonzalez D, de la Torre M, Paradela M, Ricardo F, Delgado M, Garcia J et al (2011). Videoassisted thoracic surgery lobectomy: 3-year initial experience with 200 cases, European Journal of Cardio-thoracic Surgery, 40, pp 21-28. 
8. Kim R H, Takabe K, Lockhart C G (2010). Outcomes of a hybrid technique for video - assisted thoracoscopic surgery (VATS) pulmonary resection in a community setting, $J$ Thorac Dis, 2, p. 210 - 214.

9. Kim K, Kim H K, Park J S, Chang S W, Choi Y S, Kim J et al (2010). Video-Assisted Thoracic Surgery Lobectomy: Single Institutional Experience With 704 Cases, Ann Thorac Surg, 89, pp $2118-2122$.

10. Kohno T, Sakamaki Y, Kido T, Yasukawa M (2012). Lobectomy with extended lymph node dissection by video assisted thoracic surgery for lung cancer. Surg. Endosc., 11, pp. 354-58.

11. Lee P C, Nasar A, Port J L, et al (2013). Long - Term Survival After Lobectomy for Non - Small Cell Lung Cancer by Video Assisted Thoracic Surgery Versus Thoracotomy, Ann Thorac Surg, 96, p. 951 - 961.

12. Liang C, Wen H, Guo Y, et al (2013). Severe intraoperative complications during VATS Lobectomy compared with thoracotomy lobectomy for early stage non - small cell lung cancer, J Thorac Dis, 5(4), p. 513 - 517.

13. Manser R, Graham, Wright G, Hart D, et al (2005). Surgery for early stage non-small cell lung cancer. Cochrane Database of Systematic Reviews, (1): CD004699.

14. Marty A C H, Canaud L, Solovei L, et al (2013). Video - assisted thoracoscopic lobectomy: an unavoidable trend? A retrospective single-institution series of 410 cases, Interactiveweighting, Annals of Surgical Innovation and Research, 4(1), p. 1 - 6.

15. Miller Y E (2006). Pulmonary Neoplasms. Cecil Textbook of Medicine, Eds by Bennett J.C., Plum F, 20th ed, W.B. Saunders Company, Philadelphia, pp. 436-41.
16. Nguyễn Hoàng Bình (2015). Đánh giá tính khả thi và hiệu quả phẫu thuật nội soi cắt thùy phổi trong bệnh lý phổi. Luận án tiến sĩ y học, Đại học Y Dược thành phố Hồ Chí Minh.

17. Nguyễn Khắc Kiểm (2016). Nghiên cứu nạo vét hạch theo bản đồ trong phẫu thuật điều trị ung thư phổi nguyên phát giai đoạn I, II, IIIA. Luận án tiến sĩ y học, trường Đại học $\mathrm{Y}$ Hà Nội.

18. Nomori $\mathrm{H}$, Ohtsuka $\mathrm{T}$, Horio $\mathrm{H}$, Naruke T \& i Suemasu K (2003). Thoracoscopic Lobectomy for Lung Cancer With a Largely Fused Fissure, Chest, 123, pp 619-622.

19. Sawada S, Komori E \& Yamashita M (2009). Evaluation of video-assisted thoracoscopic surgery lobectomy requiring emergency conversion to thoracotomy, European Journal of Cardio-thoracic Surgery, 36, pp 487- 490.

20. Scott W J, Matteotti R S, Egleston B $\mathrm{L}$, et al (2010). A comparison of perioperative outcomes of Video - Assisted Thoracic Surgical (VATS) Lobectomy with open thoracotomy and lobectomy: Results of an analysis using propensity score based.

21. Takizava T, et al (2007). Mediastinal lymph node metastasis in patient with clinical stage I - II peripheral non-small-cell lung cancer. J. Thorac Cardiovase Surg, vol 133, No 2, pp. 248-52.

22. Turna A, Solak O, Kilicgun A, et al (2007). Is lobe-specific lymph node dissection appropriate in lung cancer patients undergoing routine mediastinoscopy?, Thorac Cardiovasc Surg, 55(2), p. 112 - 119.

23. Walker W S, Codispoti M, Soon S Y, et al (2003). Long - term outcomes following VATS lobectomy for non - small cell bronchogenic carcinoma, European Journal of Cardio - thoracic Surgery, 23, p. 397 - 402. 
24. Yamamoto K, Ohsumi A, Kojima F, for the study of lung cancer 9th world conference et al (2010). Long - Term Survival After Video - Assisted Thoracic Surgery Lobectomy for Primary Lung Cancer, Ann Thorac Surg, 89, p. $353-359$.

25. Zhi X Y (2010). Surgical treatment of lung cancer in patients over 70 years of age. Lung cancer: Journal of the international association on lung cancer, Tokyo, Japan, pp. 145.

26. Zongren G, Mingyao C, Shen W (2009). Surgical treatment of lung cancer for elderly patients. Lung cancer: Journal of the international association for the study of lung cancer 9th world conference on lung cancer, Tokyo, Japan, pp. 145. 